pp. $147-160$

\title{
익산 쌍릉(대왕릉 : 사적 제87호) 발굴조사 개요
}

\section{이문형 - 김중엽*}

\begin{tabular}{|cl} 
[ 목 & 차 ] \\
\hline I. 조사개요 & III. 조사내용 \\
II. 문헌기록 & IV. 조사성과 \\
\hline
\end{tabular}

\section{I . 조사개요}

익산쌍릉은 행정구역상 익산시 석왕동일원으로, 남서-북동방향으로 길게 뻗은 오금산 줄기 의 말단 구릉인 해발 $45 \mathrm{~m}$ 내외의 정상부에 위치하고 있다. 대왕릉과 소왕릉은 $180 \mathrm{~m}$ 의 이격 거리를 두고 대왕릉이 북쪽에, 소왕릉이 남서쪽에 위치하고 있다.

익산쌍릉은 백제 제 30 대 왕인 무왕과 그의 비 능으로 전해져 오고 있다. 쌍릉은 이미 일제강 점기인 1910년 조선고적조사의 일환으로 간단한 현황조사가 이루어진 바 있으며, 이를 바탕으 로 1917년 일본인 야쓰이세이치谷井濟-에 의해 조사된 바 있다. 당시 조사는 유물 수습을 목적으 로 한 만큼 조사 후 13 줄의 간략한 보고문과 더불어 개략적인 실측도와 몇 장의 사진만 전해져 쌍릉의 정확한 규모나 세부구조는 파악하기 어려운 상황이었다.

2017년은 쌍릉 발굴 100주년이 되는 해로, 익산시에서는 쌍릉의 정확한 구조 및 규모 등을 통해 효율적인 정비방안의 기초자료를 확보하고자 본 연구소에 학술정밀발굴조사를 의뢰하였다. 이에 본 연구소에서는 문화재청의 허가(제2017-1450호)를 받아 2017년 7월부터 2018년 12월 21 일까지 학술발굴조사를 진행하였다.

* 원광대학교 마한·백제문화연구소 


\section{II . 문헌기록}

쌍릉에 대한 문헌기록은 『高麗史』.『高麗史節要』『新增東國舆地勝覽』 등에 보이는데 무덤 의 주인공을 '후조선 武康王', '마한시조 虎康王’ 또는 속칭 '말통대왕 능' 으로 기록하고 있는데 간략히 언급하면 다음과 같다.

『高麗史』에는 “후조선後朝鮮 무강왕武康王 및 비妃의 능이라 하였다. 속칭 말통대왕릉末通大王陵이 라 한다. 일설에 백제 무왕⿹ㅔ포의 어릴 때 이름이 서동著童인데, 말통末通은 즉 서동薯童이 변한 것이다." 라고 기록되어 있다. 또한 『고려사절요』충숙왕 16 년조에는 “3월 도적이 금마군에 있는 마한 조상 호강왕의 능을 파헤쳤으므로 이를 잡아 전법사에 넘겼는데 달아나 버렸다. 정승 정방길이 전법관을 탄핵하고자 하니 찬성사 임중연이 막으면서 '도적이 옥에 갇힌 지 2 년에 드러난 장물은 없고 죽은 자가 많습니다.'하였다. 정방길이 '무덤을 판 사람이 금이 많은 것을 본시 알았다.'하니 임중연이 부끄러워하고 성내었다 하였다.”라고 기록되어 있다.

이들 문헌기록을 통해 쌍릉을 마한왕인 무강왕(호강왕)과 비의 능으로 인식하면서도 한편으 로는 백제시대의 무왕으로도 인식하고 있음을 알 수 있다. 더불어『고려사절요』에서 보이는 도굴기사는 간접적으로 대왕릉이 도굴되었음을 짐작하게 하는 기록이다.

이후 이러한 기록을 토대로 후대 조선시대『신증동국여지승람』을 비롯한 많은 기록에서 동일 한 내용을 찾아 볼 수 있다.

\section{III. 조사내용}

금번 발굴조사의 가장 큰 성과는 기존 확인되지 않았던 백제 왕릉의 실체를 파악할 수 있었다 는 점을 들 수 있다. 또한 일제강점기(1917년) 조사 당시의 일본인이 석실 내부를 확인하는 


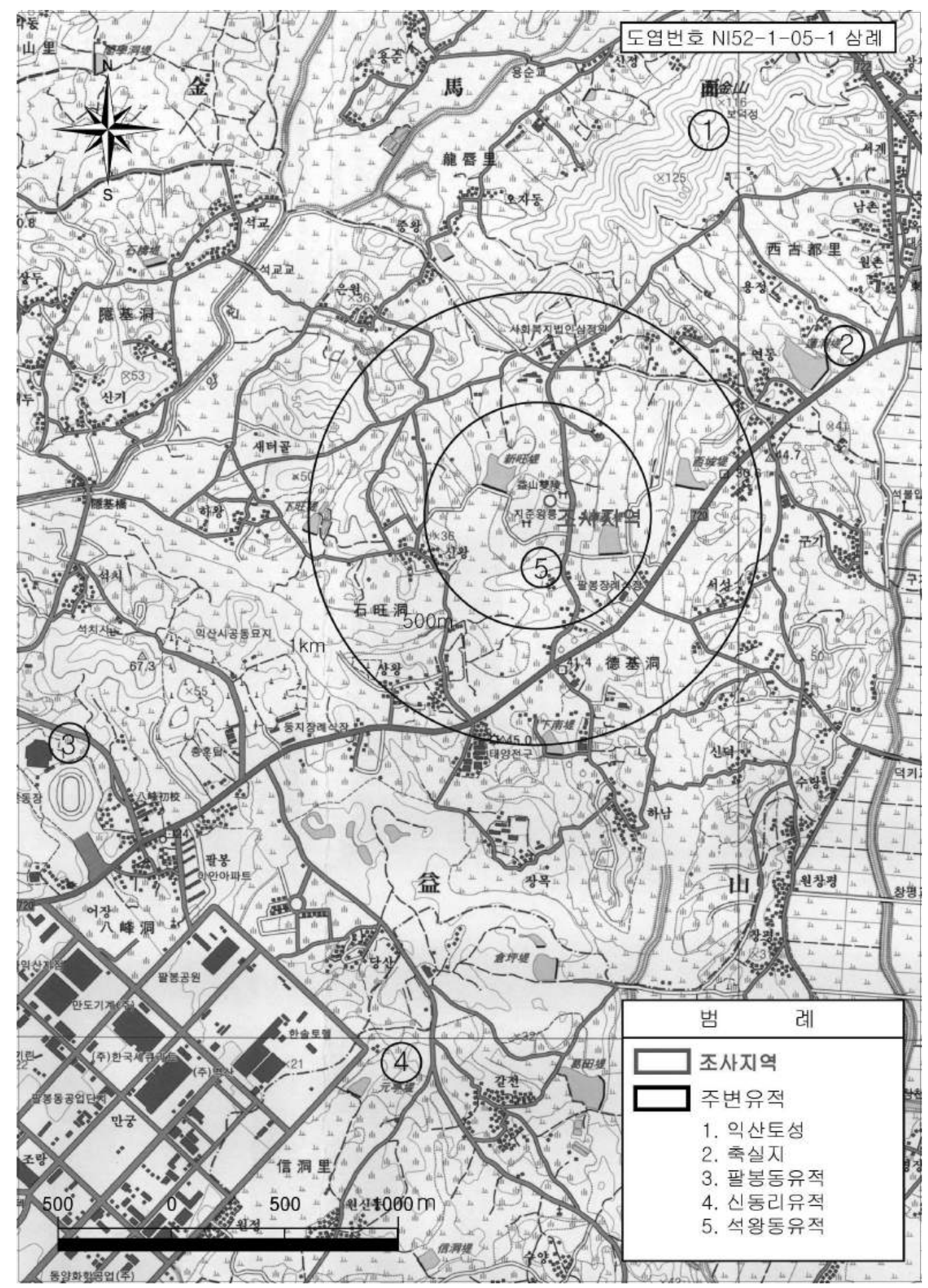

도면 1. 조사지역 및 주변유적 위치도(1:25,000) 




도면 2. 조사지역 및 주변유적 현황도(1:5,000) 
과정 역시 그 실체를 확인한 점도 주요 성과 중에 하나로 들 수 있다. 이번 조사를 통해 확인된 대왕릉의 주요 성과는 다음과 같다.

\section{1. 입지立地}

1917년 일제강점기 조사 후 작성된 대왕릉과 주변지형을 보면 오늘날과 큰 차이를 보이고 있다. 현재 대왕릉은 봉분을 중심으로 사방 $25 \mathrm{~m}$ 내외는 수평을 이루는데 이는 후대 보존하는 과정에서 정비의 결과이다.

대왕릉의 원 지형은 봉분을 중심으로 북쪽과 남쪽은 거의 수평에 가까운 평지성 구릉인데 반해 동쪽과 서쪽은 비교적 경사도를 이루고 있었던 것으로 판단된다. 이는 주변지형의 시각을 확대해 보면 알 수 있다. 쌍릉이 자리한 지형은 五金山을 기점으로 북동-남서로 뻗은 주능선에서 정남正南에 까깝게 남쪽으로 분기한 끝자락에 자리하고 있다. 이 같은 고분의 입지는 사비시기의 왕릉군인 부여 능산리고분군과 상통하는 것으로 능산리고분군을 역시 동-서로 뻗은 주능선에서 정남正南으로 분기한 가지능선의 남사면에 수 기의 고분이 작은 골짜기를 경계로 무리를 이루어 독립적으로 분포하고 있다. 따라서 사비시기의 부여 왕릉의 입지(남-북방향)와 전체적인 큰 범위에서 동일함을 확인할 수 있다. 그러나 부여 능산리고분군이 남쪽 산사면의 약간 평탄면에 축조된 반면, 쌍릉은 저⽒⽒구릉의 정상부에 단독으로 축조된 세부적인 차이를 보이고 있다.

\section{2. 봉분封境}

봉분에 대한 조사는 동-서-남-북 방향의 ‘+' 둑을 설정한 후, 둑 옆으로 폭 $1 \mathrm{~m}$ 의 탐색트렌치 를 각 방향에 설정하여 진행하였다.

조사결과, 백제시대 원 봉분은 현재 잔디가 식재되어 있는 정상부의 높이보다 약 $20 \mathrm{~cm}$ 정도 아래에서 확인되었고, 점질토계(적갈색)와 사질토계(회백색) 등을 교차 성토하면 세밀하게 다지면서 성토하였다. 동쪽 탐색트렌치의 기반토 높이를 기준으로 잔존하는 원 봉토의 높이는 약 $380 \mathrm{~cm}$ 정도이 며, 오랜 기간 동안 삭평되었을 것으로 추정하면 원래 봉토는 이보다 더 고대하였을 것으로 추정된다. 


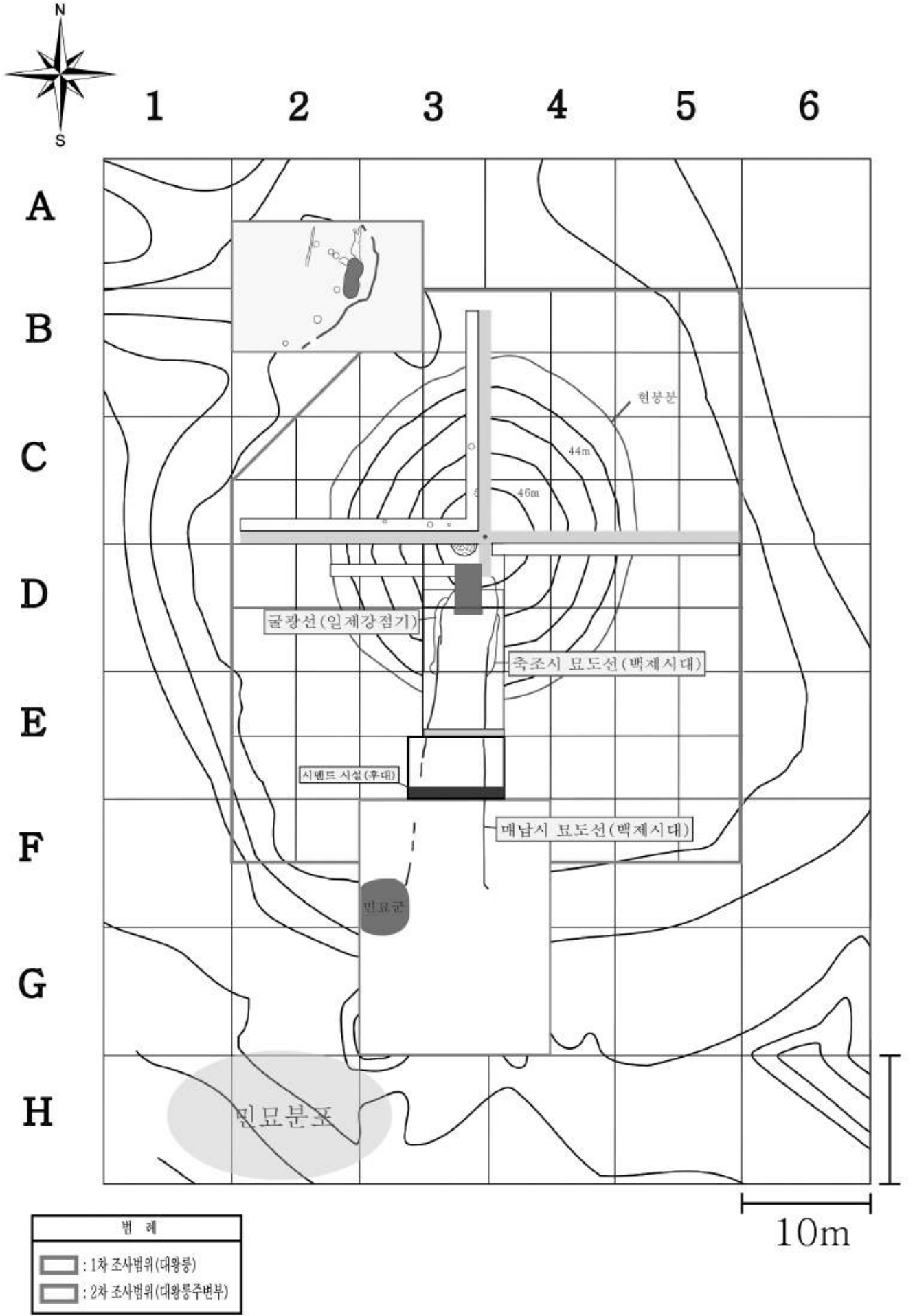

도면 3. 대왕릉 유구배치도 
각 방향에 대한 토층조사를 진행한 결과, 상대적으로 동쪽이 가장 양호하게 잔존하고 있었으며, 후대 복토 역시 그 퇴적 층이 가장 얕게 이루어졌다. 북쪽과 서쪽의 경우 $50 \mathrm{~cm}$ 이상의 후대 복토가 이루어진 부분도 확인되는데, 복토 이전 봉분의 형태를 유추해 보면, 오랜 기간 동안 삭평되거나 훼손되어 단을 이루는 곳이나 함몰되는 곳도 상당 부분 존재했었던 것으로 추정된다. 봉분의 직경은 현재 확인되는 동-서 방향을 기준으로 약 $25 \mathrm{~m}$ 정도이며, 남-북 방향으로는 묘도의 일부를 포함한다 면 그 범위는 동 서 방향보다 조금 상회할 가능성이 높다. 일제강점기 실측자료를 토대로 추정해놓은 봉분의 직경이 $30 \mathrm{~m}$ 내외로 조사 결과와 약간 차이를 보이고 있다.

성토방법에 있어 동쪽과 서쪽이 큰 차이를 보이지 않으나, 동쪽이 바깥쪽에 밀리지 않게 적갈색마사토를 이용해 외연을 쌓고 안쪽을 성토한 반면, 다른 부분은 하부에서 시작하여 상부 로 전체적으로 성토한 것으로 판단된다. 또한 석실의 개석을 중심으로 동쪽부에는 점질(진훍) 성분의 토양의 우세한 반면, 서쪽을 사질(모래)성분의 토양이 주를 이루고 있다.

가장 양호하게 잔존하는 동쪽 토층양상을 살펴보면 표토-복토층(후대정비)-교차성토층(판 축기법)-적갈색사질점토층-정지층(암적갈색점질토)-기반토 순으로 이루어져 있다. 먼저 기 반토를 비교적 평탄하게 정지한 후 $1 \mathrm{~m}$ 내외의 암적갈색점질토를 일정하게 성토하였다. 점질토 는 다른 성분의 토양이 혼입되지 않은 상태로 곱고 매우 단단하며, 중앙에서부터 일정한 높이로 이어지다 가장자리는 봉분의 사면에 따라 경사를 이루고 있다. 봉분 중심부측은 점질토를 일정 부분 굴착하였으며, 굴착된 부분에 단단하게 다져진 교차성토가 확인되고 있는데, 석실의 축조 와 관련된 층으로 판단된다. 정지층 상면에서는 토층단면에 일부 주공흔이 확인되고 있다. 정지층 위 봉분의 가장자리에는 적갈색사질점토가 비교적 두껍게 성토되어 있는데, 성토층의 유실방지를 위한 성토로 추정된다. 교차성토는 봉분의 정상부까지 이어지는데, 중앙부에는 두께 10 15cm내외의 다른 성분의 토양이 교차되며, 각 층마다 단단하게 다져진 양상을 보인다. 대체로 회흑색점질토-적갈색사질점토-회백색사질토 등이 확인되며, 중앙에서 일정한 층을 이루면서 가장자리로 이어지다 자연스럽게 층이 얇아지거나 사라지는 양상을 띤다. 층이 확인 되지 않은 가장자리에는 여러 성분의 토양이 혼입된 흑회색 점질토로 성토가 이루어져 있다. 후대의 복토층은 20 30cm정도로 백제시대 원 봉분위에 얇게 피복된 상태이다.

남쪽트렌치를 조사하는 과정에서는 1917년 일제강점기 당시 조사했던 윤곽이 그대로 노출되 었으며, 내부에서 석실이 확인되었다. 당시 굴착했던 구덩이의 규모는 동-서 약 $5 \mathrm{~m}$, 남-북 
약 $7.5 \mathrm{~m}$, 깊이 $3.3 \mathrm{~m}$ 정도이다. 1917 년 조사이후 매몰된 층은 흑회색사질점토로 단일층으로 석실의 바닥 부근에서는 연도부를 폐쇄했던 폐쇄석 1 매가 그대로 노출되었고, 남서모서리부근 에서는 금동못이 박힌 관재편과 금동관못 등이 출토되었다.

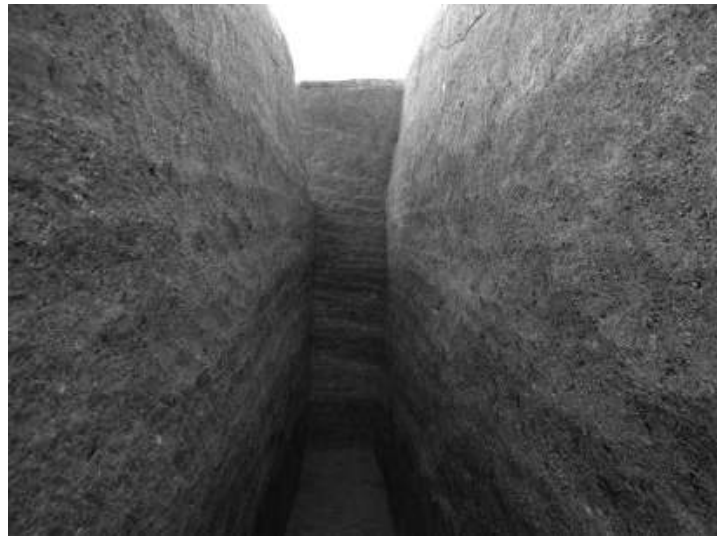

사진 1. 교차성토양상(판축기법)

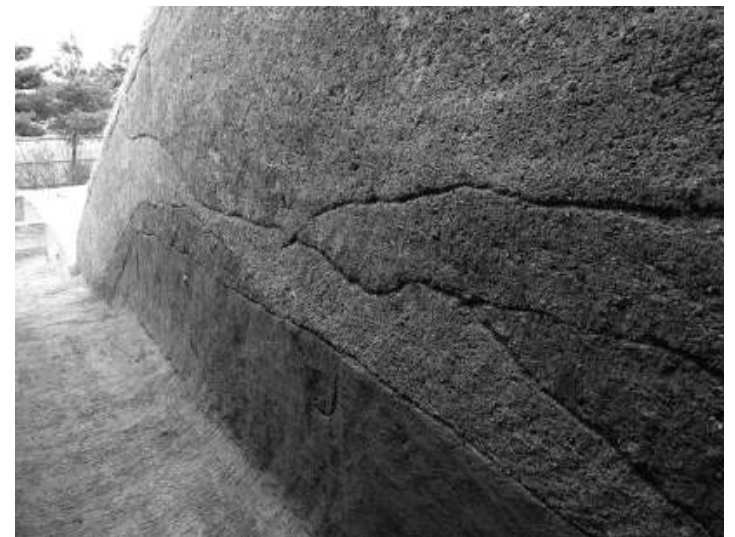

사진 2. 정지층

\section{3. 석실石室}

석실의 구조는 전형적인 사비유형의 횡혈식석실로, 평면형태는 장방형이며, 단면형태는 육 각형이다. 수직으로 세워진 벽석 위로 내경하는 고임석을 올리고 그 위로 개석을 얹은 구조라고 할 수 있다. 연도는 중앙에 짧게 달린 형태로 길이는 $70 \mathrm{~cm}$ 내외이다. 석실의 규모는 현실이 길이 $378 \mathrm{~cm}$, 너비 $178 \mathrm{~cm}$, 높이 $225 \mathrm{~cm}$ 내외로, 부여 능산리 왕릉군 중 가장 큰 동하총(길이 $326 \mathrm{~cm}$ )이나 가장 높은 중하총 $($ 높이 $215 \mathrm{~cm})$ 보다 더 크다. 따라서 석실의 주인공의 그 신분을 추정 가능하게 한다. 또한 석실의 구조와 그 짜임새는 매우 치밀하게 축조되었으며, 석재의 가공은 잔다정 기법을 사용하여 석실을 제작하였다.

현실의 구조는 북단벽은 1 매, 동장벽과 서장벽은 2 매의 판석과 그 위로 장대석 1 매를 이용하 여 축조하였다. 장벽을 구성하는 판석은 2 매로 구성되며, 1 매의 크기는 길이 $189 \sim 191 \mathrm{~cm}$, 높이 $174 \mathrm{~cm}$ 로 양 장벽이 동일하다. 고임석을 구성하는 장대석은 1 매로 현실과 같은 길이 $378 \mathrm{~cm}$, 높이는 $49 \mathrm{~cm}$ 이다. 고임석에는 대칭하여 대각선의 암맥선이 이어지는데, 하나 


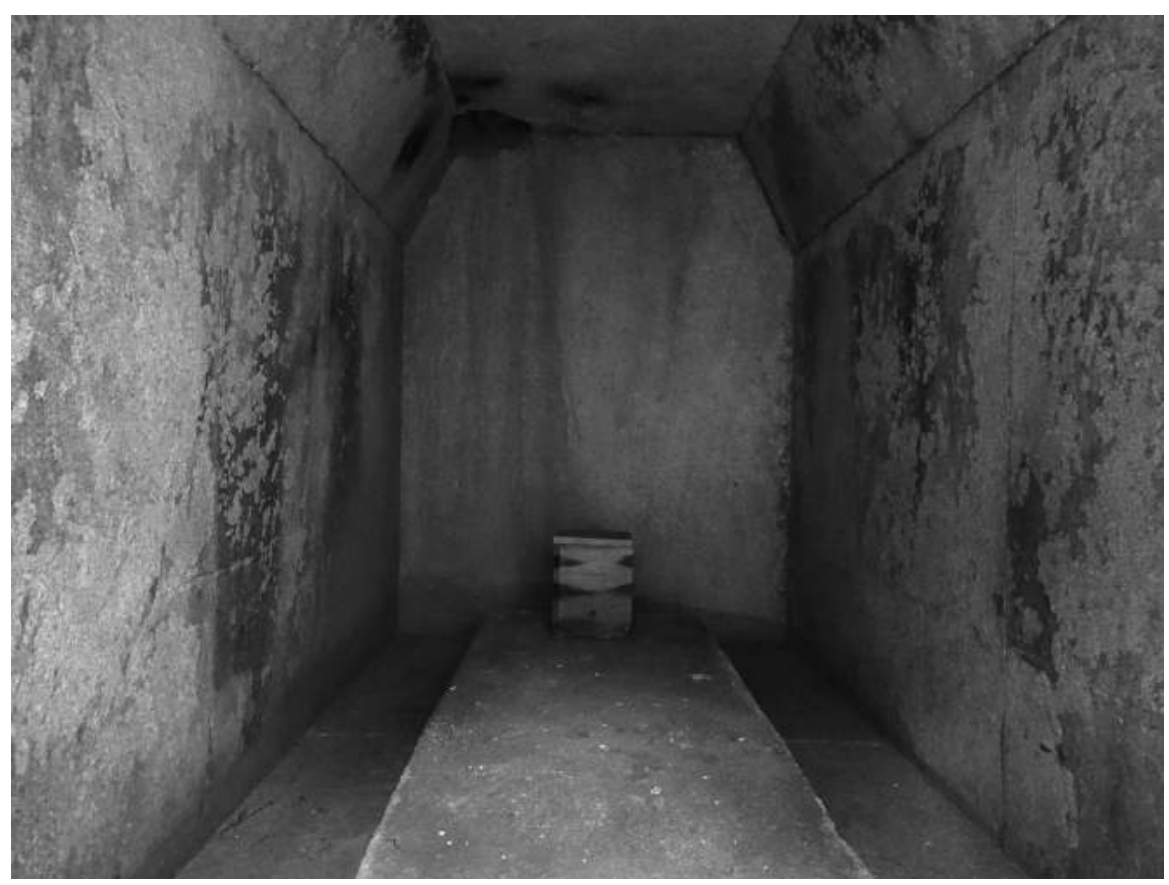

사진 3. 석실 내 전경

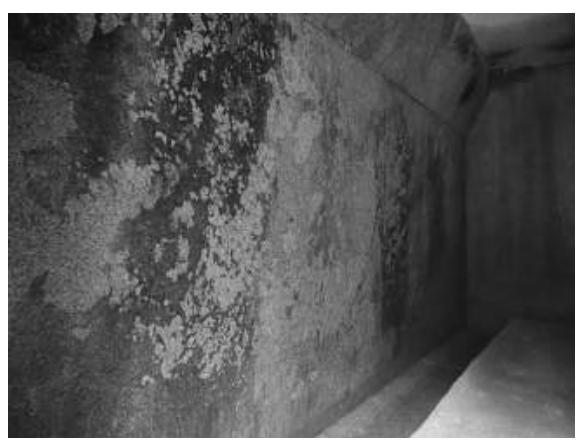

사진 4. 서장벽

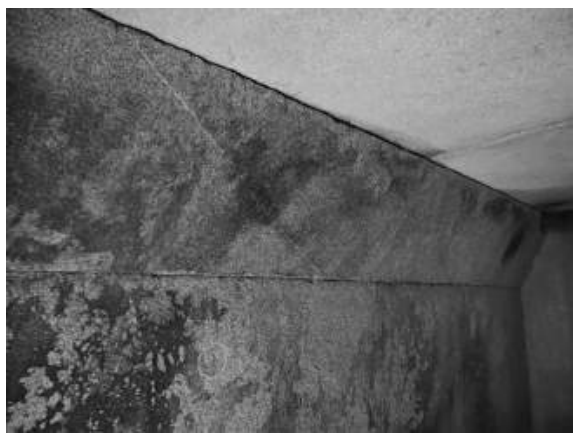

사진 6. 고임석

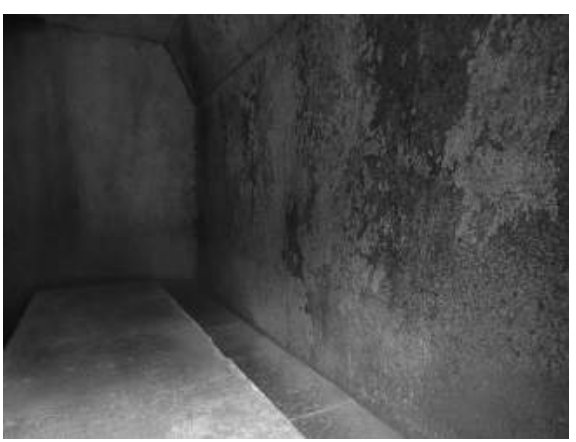

사진 5. 동장벽

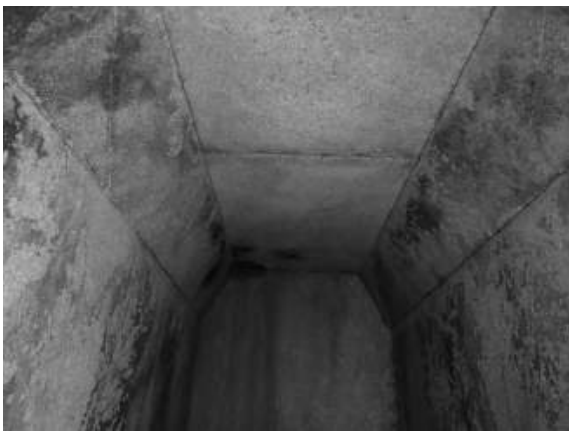

사진 7. 천장 
의 석재를 절반으로 쪼개어 사용했던 것으로 추정된다. 북단벽에는 검은색의 먹선이 희미하게 확인되는데, 단벽의 중앙과 양단에 3 줄의 세로줄이 확인되고 벽석과 고임석의 경계부분에 1 줄 의 가로줄이 희미하게 확인되고 있다.

천장은 2 매의 판석, 바닥은 3 매의 판석으로 구성되는데, 천장과 장벽을 구성하는 판석은 현실 총 길이를 2 등분하여 축조하였고 바닥은 3 등분하여 축조하였다. 남단벽은 양쪽의 문주석 과 위로 단면 육각형의 치석된 판석이 올려 있다.

현실의 입구는 너비 $100 \mathrm{~cm}$, 높이 $150 \mathrm{~cm}$ 이다. 연도는 짧게 이어지는 형태로 현실의 입구에 비해 약간 크게 축조되었다. 연도의 길이는 $67 \mathrm{~cm}$, 연도 입구는 너비 $125 \mathrm{~cm}$, 높이 $164 \mathrm{~cm}$ 정도이 다. 문미석과 문주석의 두께는 약 $30 \mathrm{~cm}$ 이다. 연도는 안쪽에서 바깥으로 살짝 벌어지게 축조하 였는데, 현실의 폐쇄석을 용이하게 넣기 위한 방책으로 생각된다. 폐쇄는 연도부와 현실입구에 각 각 1 매의 판석을 이용하였으며, 현실 폐쇄석의 가장자리에는 백회가 확인되는 것으로 보아 시신 납입 후 백회를 발라 밀봉한 것으로 판단된다.

석실 내부 중앙에는 길이 $268 \mathrm{~cm}$, 너비 $82 \mathrm{~cm}$, 높이 $24 \mathrm{~cm}$ 내외의 화강암제 관대가 놓여 있다. 관대는 단면상으로 사다리꼴에 가까우며, 상부의 모서리는 다듬어 각을 없앴다. 관대 상부에는 일제강점기 조사 사진을 통해 목관이 놓여 있었으며, 조사 후 관대는 수습되어 조선총독부박물 관에 전시된 바 있다. 목관의 수종은 분석 결과 무령왕릉과 동일한 일본 금송으로 확인된 바 있다.

금번 발굴조사에서는 관대 북쪽 끝단의 가운데에 가로 $\times$ 세로 $26 \mathrm{~cm}$, 높이 $33 \mathrm{~cm}$ 내외의 목함이 놓여 있었으며, 목함 내부에는 인골이 담겨 있었다. 목함의 표면에는 선명하게 연필로 제단한 흔적 등이 확인되는 것으로 보아 일제강점기 목관을 수습하는 과정에서 내부에서 수습된 유골 을 담아놓은 것으로 판단된다.

석실 내 북서모서리부근과 남동모서리에서 도굴과 연관된 구멍이 확인되었으며, 도굴 구멍 의 주변으로 검은 그을음 흔적이 있다. 구멍의 크기는 북서모서리가 직경 $30 \mathrm{~cm}$ 정도이며, 남동 모서리는 직경 $50 \mathrm{~cm}$ 정도이다. 명확하게 도굴된 시점은 알 수 없으나 앞 서 전술하였듯이 『고려 사절요』에 기록된 내용을 토대로 보면 고려시대에는 이루어진 것으로 추정된다. 또한 일제강 점기 내부 조사과정에서 수습된 완(토기)이 등잔으로 사용되었을 가능성을 생각해 본다면, 고려 또는 그 이전의 도굴이었을 가능성도 전혀 배제할 수 없다. 


\section{4. 묘도墓道}

묘도는 주검이 외부에서 무덤의 내부 현실로 들어가기 위한 널길이다. 즉, 관이 들어가는 길을 말하며, 무덤의 외부에서 내부에 연결되는 일종의 통로와 같은 시설이라 할 수 있다.

묘도부에 대한 조사는 먼저 1차 조사 당시 평면제토하는 과정에서 석실 앞쪽으로 서로 다른 2 개의 윤곽선이 확인되었다. 바깥쪽의 윤곽선은 내부에 회백색사질점토가 채워진 상태로 석실 입구에서부터 길이 $4.5 \mathrm{~m}$, 너비 $4.5 \mathrm{~m}$ 범위에 해당된다. 또한 또 다른 안쪽의 윤곽선은 석실 입구에서부터 남쪽의 직선방향으로 길게 이어지는 형태로 확인되었다. 전체적인 양상과 성격 을 확인하기 위해 남-북 방향으로 조사를 먼저 진행하였다. 그 결과 안쪽의 윤곽선은 묘도의 폐쇄와 관련된 것이며, 바깥쪽 윤곽선은 봉분의 축조당시 석실 앞쪽을 막고 있던 회백색사질점 토층으로 확인되었다. 즉, 미리 석실 입구부분을 회백색사질점토로 막아놓은 상태에서 후대에 굴착하여 묘도를 조성한 흔적으로 볼 수 있다. 묘도는 석실 입구에서부터 남쪽으로 길게 이어지 며, 묘도가 시작되는 지점까지의 거리는 $21 \mathrm{~m}$ 정도이다. 원래의 지형이 남쪽으로 완만한 경사를 이루며 점차 낮아지는 자연지형을 굴착하여 축조하였다.

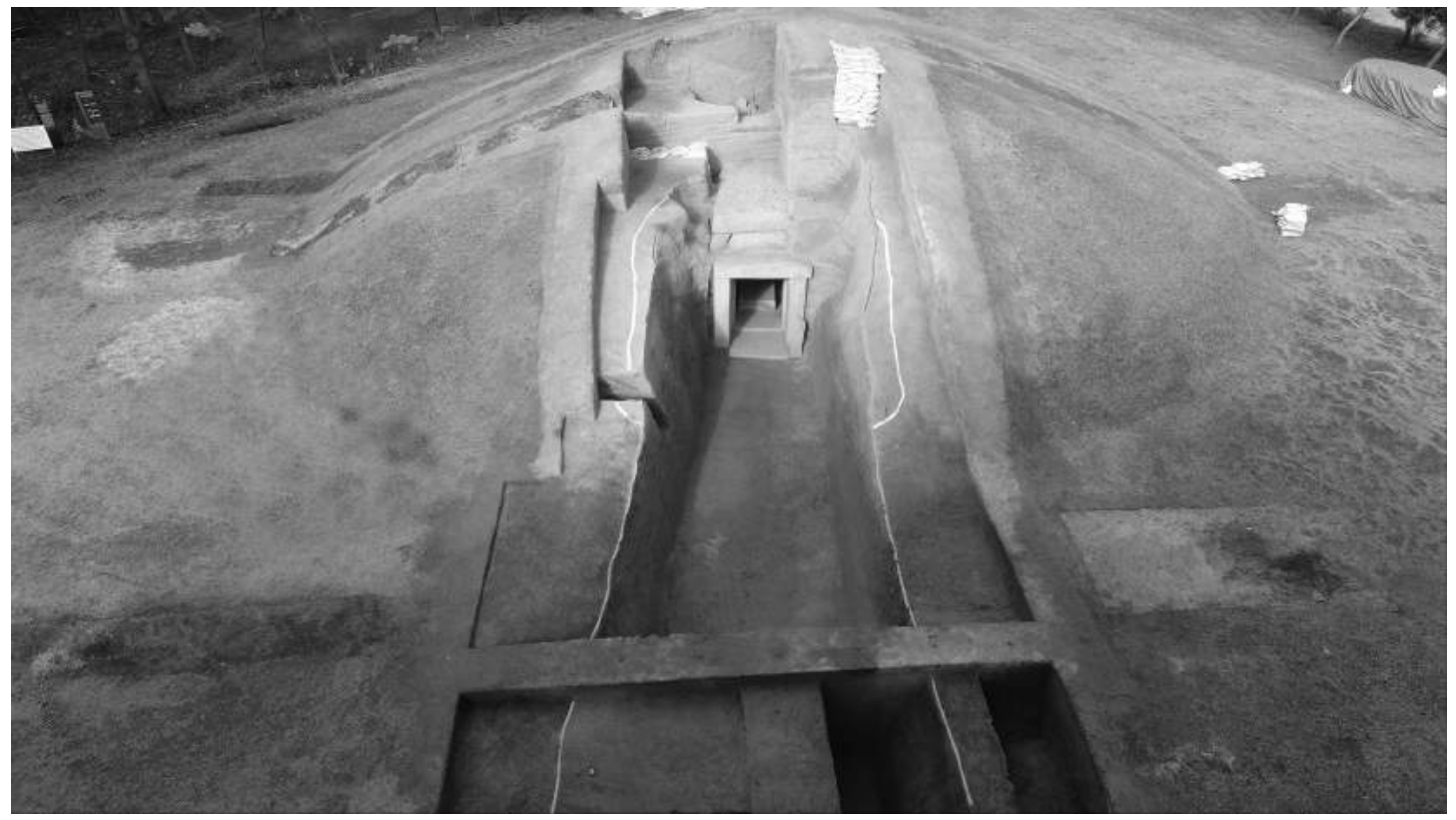

사진 8. 묘도부 전경(남-북) 
묘도는 일제강점기 조사와 후대 교란으로 인해 일부가 훼손되어 정확한 규모는 파악할 수 없지만, 석실입구 측 묘도 바닥의 너비는 $245 \mathrm{~cm}$, 상부 너비는 $375 \mathrm{~cm}$ 내외로 석실입구보다 약간 넓게 조성하였다. 또한 묘도 시점부의 바닥너비는 $440 \mathrm{~cm}$, 상부 너비는 $605 \mathrm{~cm}$ 내외로 석실입구에서 묘도 시점부까지 약 $200 \mathrm{~cm}$ 내외로 점차 넓어지는 형태를 띠고 있다. 세부적으로 묘도의 굴광의 형태를 살펴보면 동벽은 비교적 직선에 가깝게 굴광한 반면, 상대적으로 서벽은 점차 벌어지는 넓어지는 형태를 하고 있다. 묘도 바닥면은 시작 부분에서 석실입구까지 완만한 경사를 이루며 높아지다가 약 $80 \mathrm{~cm}$ 내외로 석실 앞부분이 높게 형성되어 있다. 묘도의 기반층인 풍화암반토층을 굴광하여 조성하였으며, 전반적으로 가장자리가 높고 중앙부가 약간 낮은 오 목한 형태를 띤다. 바닥면에서 주목할 만 한 인위적인 시설은 확인되지 않았다.

묘도의 축조과정을 단면 토층양상을 통해 살펴보면, 먼저 석실 앞쪽 일정 범위를 제외한 주변에 봉분조성이 이루어지고 제외된 범위 내에는 회백색사질점토를 성토하면서 표식으로서 주변과는 확연한 차이를 보인다. 이 층은 상대적으로 다짐이 되지 않아 무르고 석실 입구 및 주변에만 성토된 것으로 볼 때, 대왕릉을 미리 축조하고 표식적으로 입구부분을 막아 놓은 것으로 판단된다. 이후 주검이 안치되는 시점에 묘도를 굴착하여 조성한 후, 이 묘도를 따라 시신이 석실 내부에 안장된 것으로 추정된다.

묘도의 폐쇄는 단면조사를 통해 확인되었는데, 석실 입구로 부터 약 $8 \mathrm{~m}$ 지점까지는 황갈색사질 점토와 명적갈색사질점토 등 판축기법을 이용하여 매우 견고하고 폐쇄가 이루어진 반면, 상대적으 로 묘도의 시점부인 남쪽의 폐쇄는 크게 성토가 이루어지며, 그 다짐의 강도가 약한 편이다.

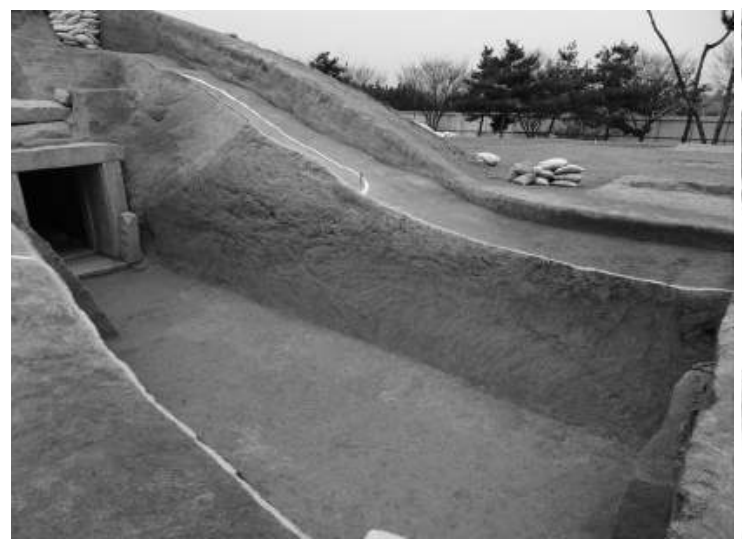

사진 9. 묘도 서벽(남서-북동)

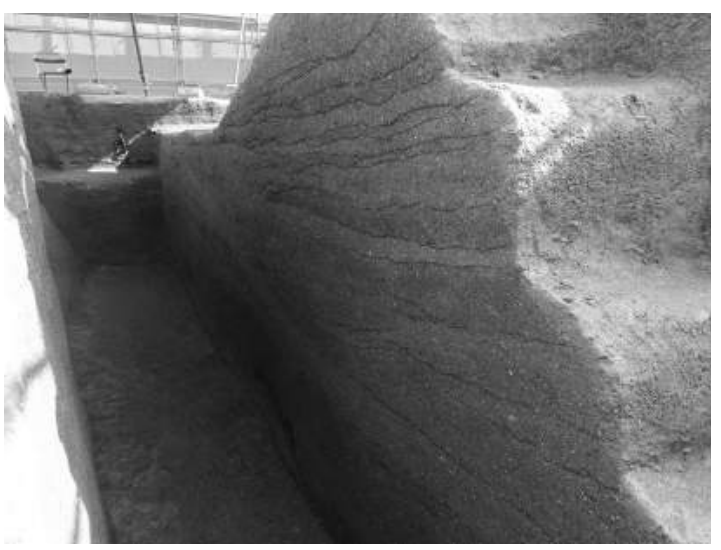

사진 10. 묘도 폐쇄양상(판축기법) 


\section{IV . 조사성과}

금번 발굴조사를 통해 사진 및 도면 등 단편적으로 확인할 수 있었던 대왕릉의 실체를 명확하 게 확인하였다는 점이 가장 큰 성과로 들 수 있다. 또한 무덤의 축조에서부터 장례와 묘도의 폐쇄에 이르기까지의 일련의 과정을 재구성할 수 있는 기초자료를 확보하였다는데 에 의미를 더할 수 있다. 그 조사 성과를 정리하면 다음과 같다.

첫째, 봉분의 규모를 확인하였다. 봉분의 높이는 기반토에서 약 $4 \mathrm{~m}$ 에 가깝게 잔존하고 있으 며, 석실 바닥을 기준으로 봉분 정상부까지는 약 $5 \mathrm{~m}$ 정도 해당된다. 직경은 동-서 기준 약 $25 \mathrm{~m}$ 로 추정되며, 현재까지 봉분 주변으로 호석 등의 시설은 확인되지 않았다. 이 결과를 바탕 으로 축조 후 그 외형을 추정해보면 주변 지형이 북쪽을 제외하고는 경사를 이루고 있어, 당시에 는 훨씬 더 高大해 보였을 것으로 추정된다.

둘째, 석실의 세부적인 축조과정을 파악하였다. 봉분의 단면 토층과 연관하여 축조과정을 살펴보면, 기반토정지-정지층마련(암적갈색점질토)-석실축조를 위한 묘광마련(되파기)-석 실축조-석실과 점질토의 교차성토(판축기법)-시신매납을 위한 묘도축조-묘도 폐쇄(교차성 토) 등 일련의 과정을 확인할 수 있었다. 석실은 벽석의 $2 / 3$ 정도가 기반토 아래에 위치하며, 고임석과 개석은 기반토 상부에 위치하게 축조하였다.

셋째, 석실은 단면 육각형의 중앙에 짧게 연도를 개설한 전형적인 사비시기의 횡혈식석실분 으로, 석재는 일정한 크기의 치석된 판석을 이용해 벽석과 천장을 구성하였다. 석재의 가공 정도는 매우 정교하고 치밀하게 축조하여 많은 노동력이 수반되었음을 짐작할 수 있다.

넷째, 묘도는 현존 최대 규모이며, 석실입구로부터 길이가 $21 \mathrm{~m}$ 이상으로 봉분과 자연지형을 굴착하여 조성하였다. 이는 주검이 현실 내부에 매납하는 과정이 얼마나 웅장하였는지를 간접 적으로 확인할 수 있으며, 이를 통해 피장자의 신분을 추정할 수 있다. 
다섯째, 조사과정의 여러 정황으로 볼 때, 대왕릉은 왕릉급 무덤임이 확실시되며, 내부에서 출토된 유골의 과학적 분석결과를 통해 그 피장자가 백제 무왕에 부합할 가능성이 매우 높다. 이는 대왕릉의 정체성이 좀 더 명확해지는 계기가 된 것으로 판단된다.

- 투고일 2018년 12월 10일 